KS. JERZY ADAMCZYK

Wyższe Seminarium Duchowne w Radomiu

\title{
NIŻSZE DIECEZJALNE SEMINARIA DUCHOWNE W POLSCE W ŚWIETLE AKTUALNYCH PRZEPISÓW PRAWNYCH
}

Treść: Wstęp. - 1. Cel niższych seminariów duchownych w Polsce $\mathrm{w}$ świetle aktualnych przepisów prawnych. -2 . Formacja w niższych diecezjalnych seminariach duchownych w Polsce. - 3. Struktura organizacyjna niższych diecezjalnych seminariów duchownych w Polsce. - Zakończenie.

\section{Wstęp}

Niższe seminaria duchowne (seminaria minora) nie mają na celu bezpośredniego kształcenia kandydatów do kapłaństwa, lecz są kościelnymi szkołami średnimi typu ogólnokształcącego, wychowującymi chłopców mających zalążki powołania i pragnących podjąć studia w wyższym seminarium duchownym, które kształci kapłanów ${ }^{1}$.

Praktyka zakładania tego rodzaju seminariów powstała w drugiej połowie XIX wieku w celu zaoferowania młodym chłopcom, którzy okazują znaki powołania kapłańskiego odpowiedniego środowiska dla ich rozwoju, wraz z możliwością wykształcenia szkolnego „klasycznego", które w tamtym okresie powoli podupadało w szkołach publicznych, niejednokrotnie będących w rękach nauczycieli

\footnotetext{
${ }^{1}$ Por. T. Pawluk, Prawo kanoniczne wedtug Kodeksu Jana Pawła II. Lud Boży jego nauczanie i uświęcanie, t. 2, Olsztyn 1986, s. 54.
} 
o poglądach pozytywistycznych i niewrażliwych na problemy religijne $^{2}$. Instytucja niższego seminarium duchownego została usankcjonowana w KPK z 1917, gdzie w kan. 1354 §2 poleca się, aby w większych zwłaszcza diecezjach starać się o założenie dwóch odrębnych seminariów: niższego, dla kształcenia chłopców w naukach z zakresu szkoły średniej oraz wyższego dla bezpośredniego przygotowania kandydatów do kapłaństwa. Sobór Watykański II wskazał na cele dydaktyczno-wychowawcze niższego seminarium duchownego, a także położył nacisk na solidną formację religijną kandydatów, zapewnienie im kierownictwa duchowego, a także włączenia w proces wychowawczy rodziców. Ponadto Sobór zaakcentował potrzebę ogólnego rozwoju chłopców według zasad zdrowej psychologii, uwzględniającej wiek i mentalność uczniów. Ojcowie soborowi polecili, aby program nauczania w niższych seminariach tak opracować, aby absolwenci nie podejmujący studiów w wyższym seminarium duchownym, mogli się kształcić na innych uczelniach wyższych. Kwestię małego seminarium duchownego reguluje KPK z 1983 r. ${ }^{3}$, zaś papież Jan Paweł II w adhortacji apostolskiej Pastores dabo vobis $\mathrm{w} \mathrm{nr} 63$ podkreśla znaczenie niższych seminariów duchownych w odkrywaniu, pielęgnowaniu i rozwijaniu powołania do kapłaństwa, a także ich rolę w duszpasterstwie powołańn

\footnotetext{
${ }^{2}$ Por. G. Trevisan, La normativa sui seminari minori, Quaderni di diritto ecclesiale 3(1990) z. 1, s. 311.

${ }^{3}$ Kan. 234 §1; por. F. MARChISANo, L'evoluzione storica della formazione del clero, Seminarium 13(1973) nr 2, s. 315.

${ }^{4}$ Ioannes Paulus PP. II, Adhortatio Apostolica Postsynodalis: Pastores dabo vobis [25 marti 1992], nr 63, AAS 84(1992), s. 657-804, (odtąd : PDV) ; por. E. ZIEMANN, Seminarium duchowne, w: Encyklopedia Katolicka, pod red. E. Gigilewicza, t. 17, Lublin 2012, k. 1396 -1397; Według KPK z 1917 r. w ramach jedynego pojęciu seminarium - to znaczy miejsca, gdzie uprawia się ziemię i kształtują się ewentualne powołania kapłańskie - różnica między „niższym” a „wyższym” seminarium tkwiła przede wszystkim w różnym rodzaju dyscyplin naukowych, które uczniowie winni zrealizować. Por. D. Cito, Comentario al can. 234, w: Comentario exegético al Código de Derecho Canónico, pod red. A. Marzoa, J. Miras, R. Rodríguez-Ocaña, t. 2, wyd. 2, Pamplona 1996, s. 219; P. Composta, Commento al 234, w: Commento al Codice di Diritto Canonico, pod red. P. Pinto, Roma 1985, s. 141. Praktyka zakładania
} 
W Polsce, szczególnie w okresie międzywojennym, a także w pierwszych latach po zakończeniu II wojny światowej powstało stosunkowo dużo niższych seminariów duchownych diecezjalnych i zakonnych. Niestety większość z tych szkół została zamknięta przez władze komunistyczne w okresie powojennym. Obecnie funkcjonują w Polsce dwa diecezjalne niższe seminaria duchowne: archidiecezji częstochowskiej w Częstochowie (założone w 1951 r.) ${ }^{5}$ i diecezji płockiej w Sikorzu (założone 1916 r. w Płocku, a w 1998 r. przeniesione do Sikorza 6 .

Niniejszy artykuł jest poświęcony niższym diecezjalnym seminariom duchownym w Polsce w świetle aktualnych przepisów prawnych.

\section{Cel niższych seminariów duchownych w Polsce $\mathrm{w}$ świetle aktualnych przepisów prawnych}

Skoro Sobór Watykański II ${ }^{7}$, jak i Kodeks Prawa Kanonicznego z 1983 r. $^{8}$ polecają zachować, a nawet, gdy biskup diecezjalny uzna to za pożyteczne, utworzyć niższe seminarium duchowne, to jawi się

seminariów niższych podczas dyskusji na Soborze Watykańskim II została poddana ostrej krytyce ze względu na przypadki braku dojrzałości wśród wychowanków tego rodzaju seminariów. Ostatecznie Sobór Watykański II zajął w tej sprawie stanowisko umiarkowane (OT 3), które zostało potwierdzone w KPK 83. Por. J. Krukowski, Komentarz do kan. 234, w: Komentarz do Kodeksu Prawa Kanonicznego. T. 2. Ks. II (1). Lud Boży, pod red. J. Krukowskiego, Poznań 2005, s. 58; D. Cito, Comentario al can. 234, s. 219. W sposób wyczerpujący oraz nie mniej interesujący ukazuje historię niższych seminariów duchownych S. Bista w artykule Instytucja niższych seminariów duchownych diecezjalnych przykładem wpływu prawa partykularnego na kościelne prawo powszechne, Śląskie Studia Historyczno-Teologiczne 4(1971), s. 161-185.

${ }^{5}$ Por. Drugi Synod Diecezji Częstochowskiej, Chrystus świattem, Maryja wzorem, Częstochowa 1987, nr 2. 2, s. 181.

${ }^{6}$ Por. W. GóR ALSKI, 300 lat seminarium duchownego w Płocku - wczoraj i dziś. (Szkic do dziejów), Studia Płockie 38(2010), s. 29; 33.

${ }^{7}$ Concilium Oecumenicum Vaticanum II, Decretum de Institutione sacerdotali Optatam Totius, [28 octobris 1965], nr 3, AAS 58(1966), s. 713-727, tekst polski: Sobór Watykański II. Konstytucje, dekrety, deklaracje. Tekst polski. Nowe tłumaczenie, Poznań 2002, s. 288-301, (odtąd: OT).

${ }^{8}$ Kan. 234. 
pytanie, jaki jest cel tej instytucji kościelnej, czemu ma ona służyć, jak powinna być realizowana formacja, aby cel małych seminariów mógł być osiągany?

Obowiązujący Kodeks Prawa Kanonicznego podkreśla, że celem niższego seminarium duchownego jest „wspieranie powołan”, a według Kodeksu Kanonów Kościołów Wschodnich jest nim kształcenie przede wszystkim tych, którzy zdają się okazywać przejawy powołania do świętej służby, aby mogli je łatwiej i jaśniej rozeznać oraz ukształtować w duchu poświęcenia ${ }^{10}$. Zgodnie z Direttorio per il ministero pastorale dei vescovi "Apostolorum Successores" seminarium niższe, to szczególna wspólnota chłopców, gdzie są pielęgnowane i rozwijane zalążki powołania kapłańskiego ${ }^{11}$, natomiast aktualne Ratio fundamentalis institutionis sacerdotalis przypomina, że zasadniczym celem niższego seminarium jest to, aby chłopcy, którzy, jak się wydaje, okazują zalążki powołania, otrzymali pomoc do łatwiejszego rozpoznania swojego powołania i pójścia za jego głosem $^{12}$. Dekret Optatam Totius Soboru Watykańskiego II orzeka autorytatywnie, że seminaria niższe są zakładane do pielęgnowania zalążków powołania, aby alumni mogli pójść wielkodusznie

\footnotetext{
${ }^{9}$ Kan. 234 §1. Schemat KPK z 1977 r. mówił, że celem seminariów niższych jest wspieranie powołań (vocationum fovendarum gratia). Pontificia Commissio Codici Iuris Canonici Recognoscendo, Schema De Populo Dei, Typis Polyglottis Vaticanis 1977, tekst polski: Posoborowe Prawodawstwo Kościelne, t. 10 z. 2, can. 85 §1, s. 161.

${ }^{10} \mathrm{Kan} .331 \S 1$.

${ }^{11}$ Congregaticio pro Episcopis, Direttorio per il ministero pastorale dei vescovi "Apostolorum Successores” [22 febbraio 2004], nr 86, Città del Vaticano 2004, tekst polski: Kongregacja do sPRAW BISKupów, Dyrektorium o pasterskiej posłudze biskupów „Apostolorum Successores” [22 lutego 2004], Kielce 2005, (odtąd: AS).

${ }^{12}$ Sacra Congregazione per L'educazione Cattolica, Ratio fundamentalis institutionis sacerdotalis [6 ianuarii 1970], nr 11, AAS 62(1970), s. 321-384, editio apparata post Codicem iuris canonici promulgatum [19 marzo 1985], Typis Polyglottis Vaticanis 1985. „Pamiętać również trzeba, że wśród alumnów są tacy, którzy otwarcie zwracają się ku kapłaństwu, tacy którzy dopuszczają je jako możliwość, wreszcie tacy, którzy się wahają i okazują wątpliwości co do powołania, lecz odznaczają się dobrymi przymiotami i nie wykluczają zupełnie nadziei, że i oni mogą dojść do kapłaństwa”. Tamże, nr 13.
} 
i z czystym sercem za Chrystusem Odkupicielem ${ }^{13}$. Autorzy listu okólnego Les Petits Séminaires zastrzegają, że instytucja seminarium niższego jest przeznaczona dla młodzieńców, którzy wykazują oznaki lub zaakceptowali możliwość powołania kapłańskiego ${ }^{14}$, a dokument L'institution des petits séminaires podkreśla, że seminarium mniejsze jest zwyczajnym miejscem, chociaż nie jest konieczne, do kultywowania powołania kapłańskiego ${ }^{15}$.

Z zaprezentowanych przepisów jasno ukazuje się cecha charakterystyczna niższego seminarium duchownego, a jest nią jego wymiar powołaniowy, co podkreślił dekret Optatam Totius mówiąc, iż przez specjalną formację religijną, zwłaszcza zaś przez odpowiednie kierownictwo duchowe, alumni mogą pójść wielkodusznie i z czystym sercem za Chrystusem Odkupicielem ${ }^{16}$.

Jest jasne, że identyczny cel posiadają polskie niższe diecezjalne seminaria duchowne. Statut Niższego Seminarium Duchownego Archidiecezji Częstochowskiej w Częstochowie w kilku miejscach wyraźnie podkreśla powołaniowy cel tej szkoły. I tak przypomina się, że szkoła ta dostępna jest dla młodzieży męskiej, wyznającej wiarę katolicką, która pragnie w niej realizować swą edukację i akceptuje jej statut. Reguła ta odnosi się szczególnie do młodych, którzy pragną pielęgnować i rozwijać oznaki powołania kapłańskiego lub zakonnego ${ }^{17}$.

\footnotetext{
${ }^{13} \mathrm{OT}, \mathrm{nr} 3$.

${ }^{14}$ Sacrée Congrégation pour L'éducation Catholique, Lettre circulaire aux Ordinaires des lieux Les Petits Séminaires [23 mai 1968], w: X. Ochoa, Leges Ecclesiae post Codicem iuris canonici editae, vol. III, Roma 1972, col. 5373.

${ }^{15}$ SaCrée Congrégation pour L'éducation Catholique, Note L'institution des petits séminaires à propos des petits séminaires [7 juin 1976], nr 2, w: Enchiridion Vaticanum, t. 5, Bologna 1990, nr 2054-2064.

${ }^{16}$ Por. OT, nr 3. Należy zauważyć, że kan. 234 § 1 traktuje jednakowo, z racji celów (powołaniowych), którym służą, niższe seminaria lub inne tego rodzaju instytucje, które w Optatam Totius ukazują się jako odrębne (OT, 3, 1 - 2), jednak wyraźnie odróżnia te rzeczywistości, które z definicji mają charakter powołaniowy, od zwyczajnej szkoły katolickiej.

${ }^{17}$ Por. Statut Niższego Seminarium Duchownego Archidiecezji Częstochowskiej $w$ Częstochowie [1 lutego 2011], § 2, nr 3, Wiadomości Archidiecezji Częstochowskiej
} 
Następnie podkreśla się, że ze swojej natury niższe seminarium duchowne ma w sposób szczególny stwarzać klimat otwarty na powołania kapłańskie tak, aby po ukończeniu tej szkoły uczniowie mogli wybrać drogę życia kapłańskiego lub zakonnego ${ }^{18}$.

Identyczne cele posiada niższe seminarium duchowne diecezji płockiej. Według Regulaminu tej szkoły seminarium jest wspólnotą dydaktyczno - wychowawczą, której podstawowym celem jest kształcenie i wychowanie chłopców w duchu patriotycznym i katolickim, pomaganie im w odkrywaniu powołania życiowego, zwłaszcza do posługi kapłańskiej ${ }^{19}$. Dalej mówi się, iż praca wychowawcza we wspomnianej instytucji winna mieć przede wszystkim na uwadze pomoc udzielaną uczniom w odkryciu i pielęgnowaniu ich życiowego powołania ${ }^{20}$ oraz, że seminarium realizuje swoje cele poprzez zapewnienie wychowankom formacji powołaniowej ${ }^{21}$. Z kolei stwierdza się, że ojciec duchowny odpowiada za formację religijną, duchową i powołaniową ${ }^{22}$.

Statut Katolickiego Liceum Ogólnokształcacego im. św. Stanisława Kostki w Sikorzu zawiera następujący zapis: „integralną częścią Liceum jest internat, w którym uczniowie Liceum są formowani w duchu katolickim. Szczególną troską są objęci uczniowie mający zamiar wybrać w przyszłości drogę powołania kapłańskiego"23.

\footnotetext{
85(2011), nr 1-3, s. 33.

${ }^{18}$ Por. tamże, §5, nr 2, s. 35.

${ }^{19}$ Por. Regulamin Niższego Seminarium Duchownego Diecezji Płockiej. Niższe Seminarium Duchowne Diecezji Płockiej. Sikórz 83 A, gmina Brudzeń Duży. Archiwum bieżące. Teczka: Regulamin Niższego Seminarium Duchownego Diecezji Płockiej, Cele i środki działania, nr 1.

${ }^{20}$ Por. tamże, Cele i środki działania, nr 3; por. XLII Synod Diecezji Płockiej (19871991), Płock 1992, st. 78 §1, s. 91.

${ }^{21}$ Por. Regulamin Niższego Seminarium Duchownego Diecezji Płockiej, Cele iśrodki działania, nr 6.

${ }^{22}$ Por. tamże, Ojciec Duchowny, nr 1; por. tamże, Zasady przyjmowania uczniów.

${ }^{23}$ Statut Katolickiego Liceum Ogólnokształcąego im. św. Stanisława Kostki. Archiwum bieżące. Teczka: Statut Katolickiego Liceum Ogólnokształcącego im. św. Stanisława Kostki, §4, nr 1. Trzeba dodać, że wychowankowie Niższego Seminarium Duchownego Diecezji Płockiej w Sikorzu uczęszczają na zajęcia
} 
Ukazując cel omawianych seminariów nasuwa się zasadnicza uwaga. Statut Niższego Seminarium Duchownego Archidiecezji Częstochowskiej $w$ Częstochowie przewiduje też możliwość przyjmowania chłopców, którzy nie rozpoznają formalnie swojego powołania, o czym świadczą np. następujące słowa: „szkoła dostępna jest dla młodzieży męskiej, wyznającej wiarę katolicką, która pragnie w niej realizować swą edukację i akceptuje jej statut. Zasada ta odnosi się w szczególności (podkreślenie J.A.) do młodzieży, która pragnie pielęgnować i rozwijać oznaki powołania kapłańskiego lub zakonnego"24 czy „nauczanie i wychowanie realizowane w Niższym Seminarium Duchownym opiera się na chrześcijańskiej wizji człowieka, głoszonej przez Kościół Katolicki i ma na celu pełny rozwój osoby, co w konsekwencji prowadzi do wewnętrznej integracji oraz przygotowuje do wyborów życiowych w oparciu o rozpoznane powołanie"25.

Podobnie jest w przypadku Niższego Seminarium Duchownego Diecezji Płockiej, gdzie mówi się, że „seminarium jest wspólnotą dydaktyczno - wychowawczą, której podstawowym celem jest kształcenie i wychowanie młodzieży męskiej w duchu patriotycznym i katolickim, udzielanie dorastającej młodzieży pomocy w odkrywaniu powołania życiowego, zwłaszcza do posługi kapłańskiej (podkreślenie J.A.), czy „praca wychowawcza powinna mieć przede wszystkim na uwadze pomoc udzielaną uczniom w odkryciu i pielęgnowaniu ich życiowego powołania". Tak więc przyjmuje się do tego seminarium także chłopców, którzy nie rozpoznają formalnie swojego powołania.

Podczas prac nad rewizją Kodeksu pojawiła się pewna trudność z jasnym ukazaniem cech charakterystycznych seminarium niższego, w szczególności, gdy chodzi o uczniów, których można przyjąć. Początkowo konsultorzy byli za tym, aby przyjmować także tych,

\footnotetext{
lekcyjne do Katolickiego Liceum Ogólnokształcącego im. św. Stanisława Kostki w Sikorzu. Formacja powołaniowa odbywa się w ramach zajęć internatu. Samo wspomniane Liceum jest szkołą koedukacyjną.

${ }^{24}$ Statut Niższego Seminarium Duchownego Archidiecezji Częstochowskiej, §2, nr 3, s. 33.

${ }^{25}$ Tamże, §2, nr 4, s. 33.
} 
który nie dążą do kapłaństwa. Stwierdzono, że w seminariach mniejszych i w podobnych instytucjach, gdy takie istnieją, dopuszcza się młodych z odpowiednimi kwalifikacjami, nawet jeżeli nie czują się powołani do świętych posług ${ }^{26}$. Swoje stanowisko konsultorzy motywowali faktem, że w określonych seminariach już tak się dzieje ${ }^{27}$ oraz że „zakres [funkcjonowania seminarium] musi być szerszy, ponieważ nadzieja posiadania powołania może pojawić się później”28.

W Schemacie KPK z 1977 r. w kan. 85 §2 umożliwiano, jeśliby było to wskazane i wyraziłaby na to zgodę Konferencja Biskupów, dopuszczenie do seminarium niższego młodzieńców wyróżniających się postawą moralną, którzy jednak nie czują się powołani do świętej posługi. Na skutek interwencji Kongregacji do spraw Wychowania Katolickiego, a także licznych biskupów dyspozycję tę usunięto, w celu zachowania podstawowej cechy charakterystycznej seminarium niższego, jako instytucji powołaniowej ${ }^{29}$. Powrócono w ten sposób do idei soborowej, ponieważ „nie wydaje się dobrym, faktycznie byłaby to ciężka szkoda, przyjmować do seminarium wszystkich, gdyż musi ono zawsze zachowywać swoją cechę charakterystyczną"30. Odrzucono więc kan. 85 \$2 Schematu

\footnotetext{
${ }^{26}$ Por. Communicationes 8(1976), s. 128.

${ }^{27}$ Por. Communicationes 8(1976), s. 129.

${ }^{28}$ Communicationes 8(1976), s. 112.

${ }^{29}$ Pontificia Commissio Codici Iuris Canonici Recognoscendo, Schema canonum Libri II De Populo Dei, can. 85 §2, Città del Vaticano (Typis Polyglottis Vaticanis) 1977, tekst polski: Posoborowe Prawodawstwo Kościelne, t. 10 z. 2 nr 19435, s. 161; por. SaCra Congregatio pro Episcopis, Directorium Ecclesiae imago de pastorali ministerio Episcoporum [22 februarii 1973], nr 194, Enchiridion Vaticanum, t. 4, Bologna 1997 nr 1945-2328, tekst polski: E. Sztafrowski, Posoborowe Prawodawstwo Kościelne, t. 6, z. 1, nr 10370-11035, (odtąd: EI); Codex Canonum Ecclesiarum Orientalium. Auctoritate Ioannis Pauli PP. II promulgatus, Typis Polyglottis Vaticanis 1990 oraz AAS 82(1990), s. 1033-1363, tłumaczenie polskie: Kodeks Kanonów Kościołów Wschodnich, Lublin 2002, kan. 331 §1.

${ }^{30}$ Communicationes 9(1977), s. 36; por. G. Trevisan, La normativa sui seminari minori, s. 92.
} 
KPK z 1977 r. ponieważ „w przeciwnym razie stałaby się pusta sama postać seminarium niższego"31.

Tym niemniej dopuszcza się, aby w przypadkach szczególnych (modo tantum exceptionali) biskup mógł przyjąć do małego seminarium chłopca, który nie czuje oznak powołania kapłańskiego, jeśli jest to naprawdę konieczne $\mathrm{w}$ danych okolicznościach ${ }^{32}$.

W myśl tego, co powiedziano, wydaje się, że przyjmowanie (z zasady, na sposób stały) do seminarium niższego chłopców, którzy ani oni sami, ani ich rodziny nie okazują, czy nie dostrzegają zalążków powołania kapłańskiego ${ }^{33}$, grozi utratą przez dane seminarium jego cechy charakterystycznej - profilu powołaniowego - i uczynienia go zwykłą szkołą katolicką.

\section{Formacja $w$ niższych diecezjalnych seminariach duchownych w Polsce}

Według kan. $234 \S 1 \mathrm{w}$ niższych seminariach, mając na uwadze wspieranie powołań wraz z wykształceniem humanistycznym i naukowym, należy przewidzieć specjalną formację religijną. Tak więc w tego typu instytucjach - idąc po linii soborowej - należy sprzyjać zalążkom powołania poprzez szczególną formację religijną i kształcenie humanistyczno - naukowe ${ }^{34}$.

Gdy chodzi o kształcenie humanistyczno - naukowe w niższym seminarium duchownym, to winna być to taka formacja, jaką w ich kraju otrzymuje młodzież zamierzająca podjąć studia wyższe. Jest to szczególnie ważne nie tylko z tego względu, że chodzi o zdobycie

\footnotetext{
${ }^{31}$ Communicationes 13(1981), s. 160.

${ }^{32}$ Por. Communicationes 13(1981), s. 160; L. Chiappetta, Il Codice di Diritto Canonico, t. 1, wyd. 1, Napoli 1988, s. 306; G. Trevisan, La normativa sui seminari minori, s. 92.

33 „Pamiętać również trzeba, że wśród alumnów są tacy, którzy otwarcie zwracają się ku kapłaństwu, tacy którzy dopuszczają je jako możliwość, wreszcie tacy, którzy się wahają i okazują wątpliwości co do powołania, lecz odznaczają się dobrymi przymiotami i nie wykluczają zupełnie nadziei, że i oni mogą dojść do kapłaństwa”. Ratio fundamentalis institutionis sacerdotalis 1985, nr 13.

${ }^{34}$ Por. OT, nr 3.
} 
adekwatnego przygotowania ogólnego, lecz także dlatego, że autentyczna droga formacyjna winna rozwinąć harmonijnie w wychowankach wszystkie składniki ich osobowości ${ }^{35}$.

Statut Niższego Seminarium Duchownego Archidiecezji Częstochowskiej postanawia, że ukończenie tej szkoły daje możliwość uzyskanie świadectwa dojrzałości po zdaniu egzaminu maturalnego, a także dalszą naukę w szkołach wyższych lub policealnych ${ }^{36}$. Cykl kształcenia w omawianej szkole trwa trzy lata i jest realizowany w oparciu o obowiązujące przepisy dotyczące edukacji w szkołach publicznych ${ }^{37}$, a nadzór pedagogiczny nad wymienioną szkołą, zgodnie z ustawą o systemie oświaty i aktami wykonawczymi wydanymi na jej podstawie, sprawuje Śląski Kurator Oświaty ${ }^{38}$.

Drugi Synod Diecezji Częstochowskiej przypomina, że „program nauczania w Niższym Seminarium obejmuje średnie wykształcenie ogólne, o profilu humanistycznym, by jego wychowankowie mogli podjąć studia filozoficzno-teologiczne w Wyższym Seminarium lub każdy inny rodzaj studiów"39.

Natomiast uczniowie Niższego Seminarium Duchownego diecezji Płockiej w Sikorzu uczęszczają na zajęcia lekcyjne do Katolickiego Liceum Ogólnokształcącego im. św. Stanisława Kostki w Sikorzu, stąd samo przez się otrzymują formację potrzebną do podjęcia studiów wyższych w Polsce ${ }^{40}$.

W sprawie programu nauczania Niższe Seminarium Duchowne Archidiecezji Częstochowskiej spełnia warunki ustawowe przewidziane dla szkół niepublicznych posiadających uprawnienia szkoły publicznej, czyli: realizuje programy nauczania zawierające podstawę

\footnotetext{
${ }^{35}$ Zob. Ratio fundamentalis institutionis sacerdotalis 1985, nr 14; por. D. Ciтo, Comentario al can. 234, s. 220.

${ }^{36}$ Por. Statut Niższego Seminarium Duchownego Archidiecezji Częstochowskiej, $\S 2$, nr 1, s. 33.

${ }^{37}$ Por. tamże, $\$ 2$, nr 2, s. 33.

${ }^{38}$ Por. tamże, $\$ 3$, nr 1, s. 33.

${ }^{39}$ Drugi Synod Diecezji Częstochowskiej, nr 2.3.21, s. 186.

${ }^{40}$ Por. Regulamin Niższego Seminarium Duchownego Diecezji Płockiej, Obowiazki Dyrektora, nr 3; por. tamże, Obowiązki Wicedyrektora, nr 3.
} 
programową kształcenia ogólnego, przeprowadza zajęcia edukacyjne w cyklu nie krótszym oraz w wymiarze nie niższym niż łączny wymiar obowiązkowych zajęć edukacyjnych określony w ramowym planie nauczania szkoły publicznej tego typu, stosuje zasady klasyfikowania i promowania uczniów oraz przeprowadzenia egzaminów i sprawdzianów ustalone przez Ministra Edukacji Narodowej, z wyjątkiem egzaminów wstępnych, dokumentuje przebieg nauczania ustalony dla szkół publicznych, zatrudnia nauczycieli przedmiotów obowiązkowych posiadających kwalifikacje określone dla nauczycieli szkół publicznych ${ }^{41}$.

Częstochowskie Niższe Seminarium Duchowne realizując zadania systemu oświaty i wychowania w zakresie liceum ogólnokształcącego, a szczególnie: umożliwia zdobycie wiedzy i umiejętności przewidzianych dla liceum ogólnokształcącego, nieodzownych do przystąpienia do matury i uzyskania świadectwa dojrzałości, wychowuje młodzież w poszanowaniu tradycji, historii i kultury narodowej, ucząc jednocześnie otwartości i szacunku dla innych kultur i narodów, kształci zgodnie z obowiązującym prawem, według przyjętego programu nauczania, wspiera uczniów wybitnie uzdolnionych poprzez organizowanie zajęć pozalekcyjnych, pomoc w przygotowaniu do konkursów i olimpiad, możliwość realizacji indywidualnego toku nauki i indywidualnego programu nauczania, motywuje poprzez nagradzanie osiągnięć uczniów, kształtuje środowisko wychowawcze, wspomagające pełny i integralny rozwój osoby oraz udziela uczniom wsparcia opiekuńczo-wychowawczego, stwarza uczącym się potrzebującym pomocy - bardziej indywidualne wsparcie według potrzeb ucznia i możliwości szkoły, uczniom uzdolnionym może

\footnotetext{
${ }^{41}$ Por. Statut Niższego Seminarium Duchownego Archidiecezji Częstochowskiej, §4, s. 34. Identyczny program nauczania posiada Katolickie Liceum Ogólnokształcące im. św. Stanisława Kostki diecezji płockiej, do którego uczęszczają alumni tamtejszego niższego seminarium. Por. Statut Katolickiego Liceum Ogólnokształcącego im. św. Stanisława Kostki, § 5.
} 
umożliwić indywidualny program nauczania, zgodnie z odrębnymi przepisami $^{42}$.

Alumni Płockiego Niższego Seminarium Duchownego pobierają naukę w Katolickim Liceum Ogólnokształcącym im. św. Stanisława Kostki w Sikorzu, które jest niepublicznym liceum ogólnokształcącym. Cykl kształcenia w Liceum trwa trzy lata i jest realizowany w oparciu o obowiązujące przepisy dotyczące edukacji w szkołach niepublicznych o uprawnieniach szkół publicznych ${ }^{43}$. Katolickie Liceum w Sikorzu realizuje zadania systemu oświaty i wychowania w zakresie liceum ogólnokształcącego, a w szczególności: wychowuje młodzież w poszanowaniu tradycji, historii i kultury narodowej, ucząc jednocześnie otwartości i szacunku dla innych kultur i narodów, umożliwia uczniom potrzebującym pomocy - bardziej indywidualne wsparcie według potrzeb ucznia i możliwości szkoły, natomiast uczniom uzdolnionym umożliwia indywidualny program nauczania, zgodnie $\mathrm{z}$ odrębnymi przepisami ${ }^{44}$.

Drugim niezbędnym aspektem formacji w niższym seminarium duchownym jest specjalna formacja religijna. „W Seminariach Niższych, założonych do pielęgnowania zalążków powołania, należy przysposabiać alumnów przez specjalną formację religijną, zwłaszcza zaś przez odpowiednie kierownictwo duchowe, do pójścia wielkodusznie i z czystym sercem za Chrystusem Odkupicielem" ${ }^{45}$. Trzeba dodać, że nie jest to jeszcze formacja ściśle kościelna, gdyż taka będzie udziałem alumnów w wyższym seminarium duchownym, ale jest to formacja religijna $\mathrm{w}$ sensie właściwym jakiej wymaga powołanie występujące co najmniej w formie zarodkowej ${ }^{46}$.

Według Drugiego Synodu Diecezji Częstochowskiej wychowawcy Niższego Seminarium mają troszczyć się o wysoki poziom

\footnotetext{
${ }^{42}$ Por. tamże, $\S 5$, nr 3, s. 35.

${ }^{43}$ Por. Statut Katolickiego Liceum Ogólnokształcącego im. św. Stanisława Kostki, $\S 2, \mathrm{nr} 1-2$.

${ }^{44}$ Por. tamże, §10, nr 1.

${ }^{45} \mathrm{OT}$, nr 3; por. kan. 234 §1; por. G. Trevisan, La normativa sui seminari minori, s. 90 .

${ }^{46}$ Por. L. Chiappetta, Il Codice di Diritto Canonico, s. 306.
} 
i odpowiedni zakres formacji religijno-moralnej wychowanków. Mają zwracać szczególną uwagę na katechezę, życie sakramentalne, modlitwę, konferencje religijno-wychowawcze, dni skupienia i rekolekcje ${ }^{47}$.

Natomiast Statut Niższego Seminarium Duchownego Archidiecezji Częstochowskiej postanawia, że szkoła dostępna jest dla młodzieży męskiej (chłopców), wyznającej wiarę katolicką, w szczególności młodzieży, która pragnie pielęgnować i rozwijać oznaki powołania kapłańskiego lub zakonnego, co zakłada realizację formacji religijnej $^{48}$. Seminarium wspomaga młodzież w zakresie formacji religijno-moralnej i organizuje formy pomocy w tym zakresie tak, aby alumni mogli osiągnąć autentyczną i dojrzałą wiarę katolicką ${ }^{49}$.

Formacja religijna w Częstochowskim Niższym Seminarium Duchownym dokonuje się poprzez: ukazywanie uczniom prawd objawionych i ciągłe pogłębianie wiedzy religijnej, zachęcanie do częstego i intensywnego praktykowania wiary, uświadomienie uczniom obowiązku apostolstwa słowem i życiem, głoszenie konferencji, homilii, rozważań, spowiedź i kierownictwo duchowe uczniów, indywidualne rozmowy z chłopcami, spotkania formacyjne i kręgi biblijne, wprowadzenie uczniów w służbę liturgiczną, opiekę nad ruchami religijnymi w seminarium, zachęcanie do czytania publikacji i literatury religijnej, redagowanie gazetki liturgicznej i formacyjnej, przygotowanie programu na dzień skupienia oraz rekolekcje wielkopostne, a także troskę o porządek w kaplicy ${ }^{50}$.

Specjalna formacja religijna jest także istotnym aspektem formacji w Płockim Niższym Seminarium Duchownym. Statut wymienionej szkoły ukazuje cel seminarium, którym jest $\mathrm{m}$. in. zapewnienie wychowankom formacji religijno-moralnej i formacji powołanio$\mathrm{wej}^{51}$. Za formację religijną, duchową i powołaniową odpowiada

\footnotetext{
${ }^{47}$ Por. Drugi Synod Diecezji Częstochowskiej, nr 2.3.22, s. 186.

${ }^{48}$ Por. Statut Niższego Seminarium Duchownego Archidiecezji Częstochowskiej, § 2, nr 3, s. 33.

${ }^{49}$ Por. tamże, $\S 5$, nr 2h, s. 35.

${ }^{50}$ Por. tamże, § 14, s. 41; por. tamże, § 7, nr 3, s. 38, § 13, nr 1, s. 40.

${ }^{51}$ Por. Regulamin Niższego Seminarium Duchownego Diecezji Płockiej, Cele iśrodki działania, nr 6 .
} 
ojciec duchowny, który organizuje życie religijne wychowanków i czuwa nad jego realizacją, wdraża wychowanków do modlitwy, wychowuje alumnów do umiłowania liturgii i czuwa nad jej poprawnym sprawowaniem, sprawuje w kaplicy szkolnej Msze święte dla wychowanków i przewodniczy innym nabożeństwom, wygłasza cotygodniowe konferencje o tematyce religijno-moralnej, odbywa indywidualne rozmowy z poszczególnymi wychowankami, wskazuje wychowankom odpowiednią literaturę i czasopisma o tematyce religijnej, organizuje rekolekcje, dni skupienia oraz nowenny ku czci św. Stanisława Kostki, patrona Niższego Seminarium Duchownego, organizuje dyżury spowiedników oraz tworzy i prowadzi dla zainteresowanych koło liturgiczne ${ }^{52}$.

\section{Struktura organizacyjna niższych diecezjalnych seminariach duchownych w Polsce}

Kan. $234 \S 1 \mathrm{KPK} / 83$ nie nakazuje biskupom bezwzględnie zakładania seminariów niższych, ale poleca zachować je tam, gdzie istnieją, oraz erygować je, jeśli zdaniem biskupa diecezjalnego byłoby to wskazane ze względu na szczególne potrzeby, np. w razie braku dostatecznej liczby powołań kapłańskich spośród absolwentów innych szkól średnich ${ }^{53}$. Biorąc pod uwagę możliwość, iż mimo ich celów powołaniowych, niższe seminaria duchowne mogą przyjmować różne konfiguracje, zależnie od potrzeb, które ocenia biskup, przywołany kanon nie przewiduje dla tych seminariów określonej struktury

\footnotetext{
${ }^{52}$ Por. tamże, Ojciec Duchowny, nr 2; 4.

${ }^{53} \mathrm{~J}$. Herranz zauważa, że prawodawca kodeksowy polecając w kan. $234 \S 1$ zachować i popierać niższe seminaria duchowne, chciał w ten sposób usunąć wiele niesłusznych sporów, które doprowadziły do powstania prawdziwej sprzeczności polegającej z jednej strony na potwierdzeniu doniosłości seminariów niższych przez Sobór Watykański II, a ich zadziwiającą, stopniową likwidacją w bardzo wielu diecezjach, a nawet w całych regionach kościelnych. Importanza del Seminario Minore e del Seminario Diocesano, Seminarium 35(1983), nr 4, s. 511-512; por. Les Petits Séminaires, nr 1.
} 
organizacyjnej ${ }^{54}$. Wydaje się jednak, że dla owocnego pielęgnowania zalążków powołania, przynajmniej częściowo wypada naśladować w seminariach małych strukturę organizacyjną wyższych seminariów duchownych ${ }^{55}$, ale jak słusznie zauważa Gianni Trevisan jest wykluczone uczynienie niższego seminarium duchownego miniaturą seminarium wyższego, gdy chodzi o organizację i funkcjonowanie ${ }^{56}$.

Małym Seminarium Duchownym Archidiecezji Częstochowskiej kieruje rektor mianowany przez Arcybiskupa Częstochowskiego na czas nieokreślony. Reprezentuje on Niższe Seminarium Duchowne jako kościelną osobę prawną. Jest kierownikiem zakładu pracy dla zatrudnionych w seminarium nauczycieli i wychowawców oraz pracowników nie będących nauczycielami ${ }^{57}$.

$\mathrm{Na}$ czele Płockiego Niższego Seminarium Duchownego stoi dyrektor, który jest odpowiednikiem rektora. Jest on mianowany i odwoływany przez Biskupa Płockiego. Dyrektor jest jednoosobowym organem wykonawczym Niższego Seminarium Duchownego, wykonującym swój urząd w imieniu Biskupa Płockiego. Reprezentuje on Seminarium na zewnątrz, a w szczególności wobec organów administracji rządowej i samorządu terytorialnego a także we wszystkich

\footnotetext{
54 „Biskup diecezjalny winien ukierunkować niższe seminarium według formy życia odpowiedniej dla wieku, młodzieńczego rozwoju oraz zgodnie ze zdrowymi zasadami psychologii i pedagogiki”. AS, nr 86. Biskup ma swobodę w ustanawianiu organizacji niższego seminarium duchownego na terenie swojej jurysdykcji. Konferencja biskupia nie może narzucać mu formy jego seminarium małego i przeszkodzić mu w podejmowaniu inicjatyw tyczących się tej szkoły, ale winna ustalić wspólnie kierunki i zasady, które umożliwiają w danym kraju tworzenie tych seminariów $\mathrm{z}$ uwzględnieniem prawodawstwa państwowego w zakresie szkolnictwa. Por. Les Petits Séminaires, nr 5, s. 165.

${ }^{55}$ Por. D. Cito, Comentario al can. 234, s. 220; J. Krukowski, Komentarz do kan. 234, s. 58.

${ }^{56}$ La normativa sui seminari minori, s. 90.

${ }^{57}$ Por. Statut Niższego Seminarium Duchownego Archidiecezji Częstochowskiej, §9, s. 38 .
} 
sprawach wymagających podejmowania czynności prawnych o charakterze zobowiązaniowym ${ }^{58}$.

Rektor Częstochowskiego Niższego Seminarium posiada następujące uprawnienia: zatrudnia i zwalnia nauczycieli i innych pracowników seminarium, przyznaje nagrody oraz wymierza kary porządkowe nauczycielom i innym pracownikom seminarium, występuje z wnioskami, po zasięgnięciu opinii rady pedagogicznej, w sprawach odznaczeń, nagród i innych wyróżnień dla nauczycieli oraz pozostałych pracowników seminarium, odpowiada za doskonalenie zawodowe i formację religijną nauczycieli ${ }^{59}$.

Rektor Seminarium Częstochowskiego posiada liczne obowiązki, mianowicie kieruje działalnością seminarium, sprawuje nadzór pedagogiczny, realizuje uchwały rady pedagogicznej, podjęte w ramach jej kompetencji stanowiących, wyznacza główne kierunki działania i funkcjonowania szkoły, odpowiada za właściwą organizację i przebieg egzaminu maturalnego, jest upoważniony do podejmowania w imieniu Arcybiskupa Metropolity Częstochowskiego decyzji prawnych, finansowych i programowych, dysponuje budżetem seminarium pod nadzorem i kontrolą organu prowadzącego, organizuje administracyjną, finansową i gospodarczą obsługę seminarium, odpowiada za realizacje programu dydaktyczno-wychowawczego seminarium, ogłasza do publicznej wiadomości szkolny zestaw programów nauczania i szkolny zestaw podręczników, sprawuje opiekę nad uczniami i stwarza im warunki integralnego i harmonijnego rozwoju, przyjmuje i skreśla wychowanków z listy uczniów, zgodnie z zasadami zapisanymi w statucie, które nie mogą być sprzeczne z odpowiednimi przepisami prawa, ustala dodatkowe dni wolne od zajęć dydaktyczno-wychowawczych ${ }^{60}$.

\footnotetext{
${ }^{58}$ Por. Regulamin Niższego Seminarium Duchownego Diecezji Płockiej, Zarzadzanie sprawami Niższego Seminarium Duchownego, nr 2-5.

${ }_{59}$ Por. Statut Niższego Seminarium Duchownego Archidiecezji Częstochowskiej, §9, nr 1-4, s. 38 .

${ }^{60}$ Por. tamże, $\S 10$, s. 38-39.
} 
Wspomniany rektor informuje na bieżąco Arcybiskupa Metropolitę Częstochowskiego o stanie seminarium, jego osiągnięciach, trudnościach i potrzebach ${ }^{61}$. Pod ścisłą kontrolą rektora znajduje się sekretariat szkoły ${ }^{62}$.

Równie liczne są obowiązki dyrektora płockiego seminarium niższego. Prezbiter ten odpowiada za całokształt funkcjonowania seminarium, a w szczególności: kieruje działalnością administracyjną, sprawuje nadzór pedagogiczny, który realizuje poprzez: dokonywanie bieżących przeglądów pracy wychowawców, badanie wyników wychowania i opieki, ocenianie pracy wychowawców, analizowanie dokumentacji dotyczącej wychowania i opieki. Sprawuje on opiekę nad wychowankami oraz stwarza warunki harmonijnego rozwoju psychofizycznego poprzez aktywne działania prozdrowotne, dysponuje środkami określonymi w planie finansowym i ponosi odpowiedzialność za ich prawidłowe wykorzystanie, a także organizuje administracyjną, finansową i gospodarczą obsługę seminarium, wykonuje inne zadania związane $z$ działalnością i funkcjonowaniem seminarium, wynikające $z$ przepisów szczegółowych ${ }^{63}$.

Przywołany dyrektor przyjmuje i skreśla z listy wychowanków, zgodnie z zasadami zapisanymi w regulaminie seminaryjnym, współpracuje z rodzicami wychowanków, nauczycielami Katolickiego Liceum Ogólnokształcącego im. św. Stanisława Kostki w Sikorzu, zapewnia wychowankom i pracownikom seminarium bezpieczne i higieniczne warunki nauki i odpoczynku i w związku z tym organizuje szkolenia bhp dla wychowanków i pracowników ${ }^{64}$.

W seminarium w Sikorzu występuje wicedyrektor, którego powołuje i odwołuje Biskup Płocki ${ }^{65}$. Pełniący ten urząd zastępuje

\footnotetext{
${ }^{61}$ Por. tamże, $\$ 11$, s. 39.

${ }^{62}$ Por. tamże, §12, s. 39. „Radzie pedagogicznej przewodniczy i jej pracami kieruje rektor Niższego Seminarium Duchownego". Statut Niższego Seminarium Duchownego Archidiecezji Częstochowskiej, §16, nr 3, s. 42.

${ }^{63}$ Por. Regulamin Niższego Seminarium Duchownego Diecezji Płockiej, Obowiazki Dyrektora, $\mathrm{nr} 1$.

${ }^{64}$ Por. tamże, nr 2-4.

${ }^{65}$ Por. tamże, Zarządzanie sprawami Niższego Seminarium Duchownego, nr 2-3.
} 
dyrektora w razie jego nieobecności. Ma on następujące obowiązki: czuwa nad bieżącym działaniem seminarium, może wydawać w porozumieniu z Dyrektorem zarządzenia porządkowe ${ }^{66}$. Regulamin Niższego Seminarium $w$ Sikorzu precyzuje obowiązki wicedyrektora: odpowiada on mianowicie za pracę administracyjną i organizacyjną, a w szczególności za przygotowanie internatu do przyjęcia wychowanków, ich zakwaterowanie, opracowanie tygodniowego planu pracy alumnów, bieżącą współpracę z rodzicami (opiekunami prawnymi) chłopców, współpracę z nauczycielami Katolickiego Liceum Ogólnokształcącego w Sikorzu, jest odpowiedzialny za przygotowanie uczniów do wypełnienia zadań wynikających z życia we wspólnocie, czyli za zapoznanie ich z Regulaminem, przestrzeganie przez wychowanków Regulaminu, prowadzenie konferencji wychowawczych w grupach i rozmów indywidualnych, rozwój osobowościowy i intelektualny chłopców. Wicedyrektor sprawuje opiekę nad wychowankami oraz kontroluje ich pracę $\mathrm{w}$ czasie przeznaczonym na naukę indywidualną we współpracy $\mathrm{z}$ innymi wychowawcami, pracuje nad wyrobieniem u alumnów postaw systematycznego odrabiania prac domowych, organizuje pomoc koleżeńską, doradza w kwestiach doboru lektur i programów telewizyjnych, pomaga w kształtowaniu chrześcijańskich zasad i wartości ${ }^{67}$.

Kolejnym urzędem w omawianych seminariach niższych jest stanowisko prefekta. W seminarium częstochowskim występują księża prefekci w szczególności odpowiedzialni za prowadzenie stałej formacji religijnej mianowani na wniosek rektora przez Arcybiskupa Metropolitę Częstochowskiego. Wyróżnia się tam dwa rodzaje prefektów: prefekt d/s wychowawczo-religijnych i prefekt d/s dydaktyczno-ekonomicznych. Duchowni ci są najbliższymi współpracownikami księdza rektora i sprawują bezpośrednią opiekę nad uczniami ${ }^{68}$.

\footnotetext{
${ }^{66}$ Por. tamże, Zarzadzanie sprawami Niższego Seminarium Duchownego, nr 5.

${ }^{67}$ Por. tamże, Obowiązki Wicedyrektora, nr 1-3. Wicedyrektor wydaje także szczegółowe zarządzenia dotyczące troski o ład i porządek w internacie. Por. tamże, Podstawowe zasady życia w Seminarium, nr 4.

${ }^{68}$ Por. Statut Niższego Seminarium Duchownego Archidiecezji Częstochowskiej, $\S 13, \mathrm{nr} 1-2$, s. 40.
} 
Gdy idzie o wspólne obowiązki obu prefektów, to mają oni troszczyć się, aby uczniowie zachowywali sumiennie regulamin seminaryjny i wszelkie wymagania życia wspólnotowego, wizytują sale lekcyjne i sypialnie, aby stwierdzić, jak chłopcy wykorzystują czas i zachowują porządek, stosują upomnienia wobec uczniów nie zachowujących regulaminu i prowadzą z nimi rozmowy wychowawcze, udzielają zezwoleń na wyjście z seminarium oraz na przyjmowanie gości w rozmównicy poza godzinami wyznaczonymi na odwiedziny, uczestniczą w życiu uczniów poprzez wspólną modlitwę, a także podczas rekreacji, w zajęciach sportowych i wykonywanych przez nich różnych pracach ${ }^{69}$.

Statut seminarium częstochowskiego stwierdza, że najbliższym współpracownikiem rektora w zakresie wychowania i prowadzenia specjalnej formacji religijnej jest prefekt $\mathrm{d} / \mathrm{s}$ wychowawczo-religijnych, a jego szczególnym zadaniem jest doprowadzenie alumnów do autentycznej wiary poprzez: ukazywanie uczniom prawd objawionych i ciągłe pogłębianie wiedzy religijnej, zachęcanie do częstego i intensywnego praktykowania wiary, uświadomienie obowiązku apostolstwa słowem i życiem, głoszenie konferencji, homilii, rozważań, spowiedź i kierownictwo duchowe, indywidualne rozmowy z chłopcami, spotkania formacyjne i kręgi biblijne, wprowadzenie uczniów w służbę liturgiczną, opiekę nad ruchami religijnymi w seminarium, zachęcanie do czytania publikacji i literatury religijnej, redagowanie gazetki liturgicznej i formacyjnej, przygotowanie programu na dzień skupienia oraz rekolekcje wielkopostne, troskę o porządek w kaplicy oraz wyznaczanie miejsc dla alumnów ${ }^{70}$.

Gdy chodzi o powinności prefekta d/s dydaktyczno-ekonomicznych seminarium częstochowskiego, to jego zasadniczym zadaniem jest pomoc rektorowi w organizacji procesu nauczania i czuwanie nad dyscypliną życia seminaryjnego oraz troska o bezpieczeństwo w seminarium. W tym celu: przygotowuje tygodniowy plan zajęć lekcyjnych oraz czuwa nad jego realizacją, kontroluje przestrzeganie

\footnotetext{
${ }^{69}$ Por. tamże, $\S 13$, nr 3, s. 40.

${ }^{70}$ Por. tamże, §14, s. 40-41.
} 
wewnętrznego systemu oceniania, prowadzi księgę zastępstw, organizuje bazę dydaktyczną do realizacji programów nauczania przedmiotów ogólnokształcących zgodnie z ramowymi programami nauczania, określonymi w rozporządzeniu właściwego ministra do spraw oświaty i wychowania, opiekuje się biblioteką seminaryjną i jest odpowiedzialny za czytelnictwo książek i czasopism, wyznacza miejsca uczniom w internacie, troszczy się o higienę i materialne dobra seminarium, dba o rozwój fizyczny uczniów, ich zdrowie, higienę psychiczną, racjonalny wypoczynek, prawidłową organizację nauki zgodnie z obowiązującymi przepisami prawa w sprawie bezpieczeństwa i higieny pracy, zarządza pilne remonty i naprawę uszkodzeń i zniszczeń, troszczy się o rozwój kulturalny uczniów poprzez organizowanie imprez kulturalnych, spotkań, wystaw i gazetek szkolnych, prowadzi stronę internetową szkoły ${ }^{71}$.

W Niższym Seminarium Duchownym Diecezji Płockiej występuje funkcja prefekta ds. wychowania, który należy do zarządu seminarium, a jest powoływany i odwoływany przez Biskupa Płockiego ${ }^{72}$. Regulamin Niższego Seminarium Duchownego Diecezji Płockiej precyzuje obowiązki prefekta wychowawczego. Tak więc generalnie wspomaga on wicedyrektora w bieżącym kierowaniu seminarium. W sposób szczególny jego obowiązkiem jest: troska o zdrowie i bezpieczeństwo wychowanków. Jego zadania w tej materii to organizacja opieki zdrowotnej nad wychowankami, opieka nad wychowankami chorymi, kontakt alumnów z lekarzem, odpowiedzialność za sprawy meldunkowe uczniów, za właściwe funkcjonowanie stołówki (prefekt ma obowiązek przebywać w stołówce szkolnej w czasie posiłków wychowanków), organizowanie życia kulturalnego alumnów, jak np. wyjazdów do teatru i kina oraz organizowanie spotkań z ludźmi kultury i nauki, organizacja prac porządkowych w seminarium, czuwanie nad czystością i ładem w pomieszczeniach seminarium, opieka nad wychowankami oraz kontrola ich pracy w czasie przeznaczonym

\footnotetext{
${ }^{71}$ Por. tamże, §15, s. 41-42.

${ }^{72}$ Por. Regulamin Niższego Seminarium Duchownego Diecezji Płockiej, Zarzadzanie sprawami Niższego Seminarium Duchownego, nr 2-3.
} 
na naukę indywidualną. Wymieniony kapłan prowadzi także dokumentację działalności opiekuńczo-wychowawczej seminarium ${ }^{73}$.

Odpowiednikiem funkcji prefekta $\mathrm{d} / \mathrm{s}$ wychowawczo-religijnych seminarium częstochowskiego jest w seminarium płockim urząd ojca duchownego. Kapłan ten należy do zarządu seminarium i jest mianowany i odwoływany przez Biskupa Płockiego ${ }^{74}$. Jest zrozumiałe, że ojciec duchowny jest pierwszym odpowiedzialnym za formację religijną, duchową i powołaniową. Do jego szczególnych zadań należy: organizacja życia religijnego wychowanków i czuwanie nad jej realizacją, wdrażanie chłopców do modlitwy, wychowywanie do umiłowania liturgii i czuwanie nad jej poprawnym sprawowaniem, sprawowanie w kaplicy szkolnej mszy świętych dla wychowanków i przewodniczenie innym nabożeństwom, wygłaszanie cotygodniowych konferencji o tematyce religijno-moralnej, odbywanie indywidualnych rozmów z poszczególnymi alumnami, wskazywanie im odpowiedniej literatury i czasopism o tematyce religijnej, organizacja rekolekcji, dni skupienia oraz nowenny ku czci św. Stanisława Kostki, patrona Niższego Seminarium Duchownego oraz organizacja dyżuru spowiedników ${ }^{75}$. Ponadto ojciec duchowny sprawuje nadzór nad porządkiem i czystością w kaplicy i zakrystii, a także tworzy i prowadzi dla zainteresowanych koło liturgiczne ${ }^{76}$.

W Niższym Seminarium Duchownym w Częstochowie działa rada pedagogiczna, która jest kolegialnym organem szkoły w zakresie realizacji jej zadań statutowych dotyczących kształcenia, wychowania i opieki. W jej skład wchodzą wszyscy pracownicy pedagogiczni szkoły, czyli nauczyciele ${ }^{77}$. Statut tego seminarium w wielu miejscach

\footnotetext{
${ }^{73}$ Por. tamże, Obowiązki Prefekta Wychowawczego, nr 1-3. Prefekt ds. wychowania wydaje szczegółowe zarządzenia dotyczące troski o ład i porządek w internacie. Por. tamże, Podstawowe zasady życia w Seminarium, nr 4.

${ }^{74}$ Por. tamże, Zarzadzanie sprawami Niższego Seminarium Duchownego, nr 2-3.

${ }^{75}$ Por. tamże, Ojciec Duchowny, nr 1-2.

${ }^{76}$ Por. tamże, Ojciec Duchowny, nr 3-4.

${ }^{77}$ Por. Statut Niższego Seminarium Duchownego Archidiecezji Częstochowskiej, §16, nr 1-2, s. 42. Np. „Środowisko wychowawcze Niższego Seminarium Duchownego
} 
wspomina o nauczycielach (różnych od zarządu seminarium) ${ }^{78}$. W przypadku Niższego Seminarium Duchownego w Sikorzu zajęcia dydaktyczne dla alumnów prowadzą nauczyciele Katolickiego Liceum Ogólnokształcącego im. św. Stanisława Kostki w Sikorzu ${ }^{79}$.

W strukturę Częstochowskiego Niższego Seminarium Duchownego wchodzi także nauczyciel-bibliotekarz ${ }^{80}$. O bibliotekarzu pośrednio także traktuje Regulamin Niższego Seminarium Duchownego Diecezji Płockiej, gdzie wspomina się, że do realizacji zadań opiekuńczo-wychowawczych Niższe Seminarium Duchowne zapewnia bibliotekę i czytelnię ${ }^{81}$.

Niższe Seminarium Duchowne Archidiecezji Częstochowskiej w Częstochowie zatrudnia także pracowników sekretariatu szkoły podlegających rektorowi ${ }^{82}$, a także pracowników niepedagogicznych („inni pracownicy Seminarium,) $)^{83}$. Są to pracownicy administracyjni i pracownicy obsługi ${ }^{84}$.

tworzą pracujący tutaj księża, nauczyciele, uczniowie oraz rodzice i inni pracownicy Seminarium”. Tamże, §6, nr 1-2, s. 36.

${ }^{78}$ Por. tamże, np. $\S 4$, nr 5, s. 34, §6, nr 1-2, 3c, s. 36, §9, nr 1-4, s. 38, $\$ 17,1$ h, 2 e, s. $43, \S 17, \mathrm{n} \mathrm{r} 3,5$, s. $43, \S 21, \mathrm{nr} 5$, s. $46, \S 22$, s. 47.

${ }^{79}$ Por. Regulamin Niższego Seminarium Duchownego Diecezji Płockiej, Obowiazki Dyrektora, nr 3; tamże, Obowiązki Wicedyrektora, nr 3, 5; tamże, Skreślenie z listy wychowanków, nr 2.

${ }^{80}$ Por. Statut Niższego Seminarium Duchownego Archidiecezji Częstochowskiej, $\S 24, \mathrm{nr} 4$, s. 48.

${ }^{81}$ Por. Regulamin Niższego Seminarium Duchownego Diecezji Płockiej, Cele iśrodki działania, nr 7 d-e.

${ }^{82}$ Por. Statut Niższego Seminarium Duchownego Archidiecezji Częstochowskiej, $\S 12$, s. 39.

${ }^{83}$ „Środowisko wychowawcze Niższego Seminarium Duchownego tworzą pracujący tutaj księża, nauczyciele, uczniowie oraz rodzice i inni pracownicy Seminarium”. Statut Niższego Seminarium Duchownego Archidiecezji Częstochowskiej, §6, nr 1, s. 36; por. tamże, §22, s. $47, \S 24, \mathrm{nr} 2$, s. 48.

${ }^{84}$ Por. tamże, $\S 32$, s. 53; por. tamże, §35, nr 1, s. 55. 


\section{Zakończenie}

Niższe seminaria duchowne kształcące chłopców mających zalążki powołania i pragnących studiować $\mathrm{w}$ wyższym seminarium duchownym, w celu zostania w przyszłości kapłanami, jawią się jako zwyczajne środowiska, chociaż niekonieczne, dla kultywowania powołania kapłańskiego.

KPK/83 nie nakazuje biskupom bezwzględnie zakładania seminariów niższych, ale poleca zachować je tam, gdzie istnieją, oraz erygować je, jeśli zdaniem biskupa diecezjalnego byłoby to wskazane ze względu na szczególne potrzeby, np. w razie braku dostatecznej liczby powołań kapłańskich spośród absolwentów innych szkól średnich. Obecnie funkcjonują w Polsce dwa diecezjalne niższe seminaria duchowne: archidiecezji częstochowskiej w Częstochowie i diecezji płockiej w Sikorzu, wiele innych zlikwidowano w czasach komunizmu i nie erygowano nowych.

Choć zdecydowana większość prezbiterów w Polsce nie odbyła formacji w niższym seminarium duchownym (co potwierdza, że seminaria te nie są konieczne), to jednak omówione w niniejszym artykule dwa niższe diecezjalne seminaria duchowne zostały po myśli Kodeksu zachowane, otrzymały nowe uregulowania prawne (statuty i regulaminy) i nadal mogą pełnić owocnie swoją funkcję powołaniową.

\section{Lower diocesan theological seminaries in Poland in the light of the current legislation}

The Article explores the canonical aspect of the issue of lower diocesan theological seminaries in Poland.

The first part presents the objective of lower theological seminaries in Poland in the light of current legislation.

The second part indicates the necessity of adequate formation in the lower diocesan theological seminaries in Poland, and the third part deals with the organizational structure of the schools at stake.

SŁoWA KLUCzowe: niższe seminaria duchowne, formacja, alumni, Kodeks Prawa Kanonicznego z 1983 r., powołanie kapłańskie 
KEYwORDs: lower theological seminaries, formation, alumnae, Code of Canon Law of 1983, vocation to the priesthood

Nota o Autorze:

KS. DR HAB. JERZY ADAMCZYK - wykładowca prawa kanonicznego w WSD w Radomiu, Jest autorem opracowań z zakresu prawa małżeńskiego, hierarchicznego ustroju Kościoła, sakramentów św. oraz miejsc świętych. 